DOI : https://doi.org/10.24843/JFU.2020.v09.i02.p06

pISSN: 2301-7716; eISSN: 2622-4607

Jurnal Farmasi Udayana, Spesial Issue Desember 2020, 180-186

\title{
Formulasi Dan Uji Efektivitas Penyembuhan Luka Sayat Salep Ekstrak Metanol Bunga Ginje (Thevetia Peruviana) Terhadap Kelinci Jantan New Zealand White
}

\author{
Sefi Megawati ${ }^{1}$, Ummu Choridah Ummah ${ }^{1}$, Abdul Aziz Setiawan ${ }^{1}$ \\ ${ }^{1}$ Sekolah Tinggi Farmasi Muhammadiyah Tangerang, Tangerang, Indonesia. \\ "Corresponding Author Email : sefi.megawati@gmail.com
}

Riwayat artikel: Dikirim: 04/10/2020; Diterima: 31/10/2020, Diterbitkan: 15/12/2020

\begin{abstract}
Ginje flower contains medicinal properties that are useful in the process of wound healing. The purpose of this study is to formulate an ointment of extract ginje flower (Thevetia Peruviana). Flower extract and to test the ointment to wound healing on the skin of male rabbits. This study is experimental. Flower extract used in manufecture of ointment formulation. The number of tested animals used was 5, with 6 treatment groups, ginje ointment $2,5 \%$, ginje ointment $5 \%$, ginje ointment $7,5 \%$, control positive, control negative and injures without ointment application. All rabits were injure with a wound healing of $2 \mathrm{~cm}$ long. The wound healing were applied with ointment three times daily. Observation was conducted everyday from day 0 to day 12 . All data was tested statistically using ANOVA (Analysis of Variant). Qualitative data were presented descriptively. The result showed that ginje flower formulation meets the ointment test requirentment, wound healing were narrowed, scabs were formed and then wound healing were closed. Statistical test showed that there were significant effects on wound healing in rabits male New Zealand White $(p<0,05)$. Based on the result of the study it can be concluded that the preparation of an ointment made from ginje flower met the requirenment, and consentration of $2,5 \%, 5 \%$ and $7,5 \%$ gave effect to the wound healing of open wound healing on the skin of rabits male.
\end{abstract}

Keywords: ointment, extract, ginje flower, wound healing, rabit male.

\begin{abstract}
ABSTRAK
Bunga ginje merupakan tumbuhan berkhasiat obat yang bekerja dalam proses penyembuhan luka. Tujuan dari penelitian ini adalah untuk membuat formulasi salep ekstrak bunga ginje (Thevetia Peruviana) dan uji efektivitas penyembuhan luka sayat pada punggung kelinci jantan. Jenis penelitian ini adalah eksperimental. Pembuatan formulasi salep menggunakan ekstrak bunga Ginje dengan menggunakan hewan uji sebanyak 5 (lima) ekor dengan 6 (enam) kelompok perlakuan, yaitu salep ekstrak bunga Ginje 2,5\%, salep ekstrak bunga Ginje $5 \%$, salep ekstrak bunga Ginje 7,5\%, kontrol negatif, kontrol positif dan luka tanpa perlakuan. Semua kelinci dilukai sepanjang $2 \mathrm{~cm}$ dengan kedalaman $0,1 \mathrm{~cm}$. Luka diolesi 3 kali dalam sehari dengan salep yang di uji. Pengamatan luka dilakukan setiap hari (hari ke-0 sampai ke-12). Semua data kuantitatif diuji secara statistik menggunakan ANOVA (Analisys Of Varian) sedangkan data kualitatif disajikan secara deskriptif. Hasil penelitian menunjukan formulasi salep ekstrak bunga Ginje memenuhi persyaratan uji salep, mengalami penyempitan luka, membentuk keropeng dan menutup luka. Hasil uji statistik memberikan efek signifikan terhadap penyembuhan luka pada kelinci jantan, yaitu $(\mathrm{p}<0,05)$. Berdasarkan hasil penelitian disimpulkan bahwa pembuatan salep ekstrak bunga Ginje menghasilkan sediaan salep yang memenuhi syarat dan konsentrasi $2,5 \%, 5 \%$ dan 7,5 \% memberikan efektifitas penyembuhan luka sayat pada kelinci jantan.
\end{abstract}

Kata kunci: Salep, Ekstrak, Bunga Ginje, penyembuhan luka, kelinci jantan. 
DOI : https://doi.org/10.24843/JFU.2020.v09.i02.p06

pISSN: 2301-7716; eISSN: 2622-4607

Jurnal Farmasi Udayana, Spesial Issue Desember 2020, 180-186

\section{PENDAHULUAN}

Segala aktivitas dalam kehidupan sehari-hari dapat menimbulkan risiko timbulnya luka pada tubuh. Luka atau vulnus adalah putusnya kontinuitas kulit dan jaringan dibawah kulit oleh karena trauma. Secara empiris getah daun ginje (Thevetia peruviana) dapat menyembuhkan luka sayat dengan cepat. Masyarakat dahulu menggunakan getah daun ginje (Thevetia peruviana) ketika terkena benda-benda tajam (Sutawijaya, 2009).

Penyembuhan luka sangat penting untuk mengembalikan integritasnya sesegera mungkin dan merupakan suatu proses kompleks dan dinamis dengan pola yang dapat diprediksikan. Fase proliferasi merupakan salah satu tahap penting pada penyembuhan luka dan terjadi setelah fase inflamasi (Senja, Hidayati and Setyaningsih, 2014). Beberapa alasan mengapa kelinci banyak digunakan sebagai hewan coba dalam penelitian adalah selain karena pertimbangan praktis, hewan model tersebut adalah hewan yang sangat jinak dan lembut, juga karena mudah untuk ditangani dan memerlukan perawatan yang relatif murah serta dapat berkembangbiak secara cepat. Kelinci banyak dipakai sebagai subjek penelitian. Kelinci termasuk keluarga Leporidae dari ordo Lagomorpha (Dan dkk., 2008) .

Berdasarkan hasil penelitian yang telah dilakukan oleh Thilagavathi and Kavitha (2010) dengan judul "Isolation, Characterization and Anti-Inflamatory property of Thevetia Peruviana" menunjukan adanya aktivitas antiinflamasi dari bunga ginje (Thevetia Peruviana), maka penulis ingin melanjutkan penelitian dengan membuat sediaan farmasi untuk mempermudah penggunaannya secara topikal yaitu salep, menggunakan ekstrak bunga ginje (Thevetia
Peruviana) dengan berbagai konsentrasi dan menguji efektivitasnya untuk pengobatan luka sayat. Dipilih sediaan salep karena bentuk sediaan salep lebih mudah digunakan, menyebar rata dan larut dalam air sehingga mudah dibersihkan dan tidak lengket (Anief, 2010).

Sehingga peneliti berinovasi untuk mengkaji lebih dalam lagi dengan membandingkan efektifitas salep ekstrak bunga ginje (Thevetia peruviana) dengan povidon iodin secara in vivo. Atas dasar pemikiran tersebut timbul keingintahuan peneliti untuk melakukan penelitian dengan judul "Formulasi dan Uji Efektivitas Penyembuhan Luka Sayat Salep Ekstrak Metanol Bunga Ginje (Thevetia peruviana) Terhadap Kelinci Jantan New Zealand White”.

\section{BAHAN DAN METODE}

\subsection{Bahan dan Alat}

Bahan yang digunakan pada penelitian ini adalah bunga ginje (Thivetia Peruviana) yang dikumpulkan dari perkebunan daerah Kp. Cayur Ds. Sindang Sono Kec. Sindang jaya Tangerang-Banten, Metanol 90\%, salep Povidon Iodin 10\%, Vaselin, Adeps lanae, Alkohol 70\%, dan Kelinci Jantan (New Zealand White).

Alat yang digunakan pada penelitian ini adalah kandang kelinci beserta tempat makan dan minum, surgical blade sterile (pisau bedah), seperangkat alat refluks, pisau cukur, spidol, timbangan analitik, ayakan nomor 40 mesh, alat-alat gelas antara lain gelas ukur, beker gelas, corong, tabung reaksi, dan pipet tetes. 
DOI : https://doi.org/10.24843/JFU.2020.v09.i02.p06

pISSN: 2301-7716; eISSN: 2622-4607

Jurnal Farmasi Udayana, Spesial Issue Desember 2020, 180-186

\subsection{Metode}

\subsubsection{Pembuatan ekstrak}

Pembuatan ekstrak dilakukan dengan menggunakan 500 gram serbuk kering bunga ginje (Thevetia Peruviana) dengan $1.500 \mathrm{ml}$ metanol 90\% dengan perbandingan simplisia : metanol (1:3). Kemudian dilakukan ekstraksi dengan metode refluks pada suhu $62-65^{\circ} \mathrm{C}$ selama 3 jam. Ekstrak cair yang didapat dengan metode refluks dibuat ekstrak kental dengan menggunakan Water Bath.

\subsubsection{Pembuatan salep}

Sediaan salep dibuat mengunakan formula standar dasar salep menurut Goeswin Agoes (2006)) sebagai berikut:

$\begin{array}{cc}\text { R/ Adeps lanae } & 15 \mathrm{~g} \\ \text { Vaselin album } & 85 \mathrm{~g} \\ \text { m.f. salep } & 100 \mathrm{~g}\end{array}$

Sediaan salep yan dibuat dalam penelitian ini menggunakan konsetrasi ekstrak yang berbeda-beda yaitu 2,5\%; $5 \%$ dan 7,5\% sebanyak 100 gram.

Formula I

$\begin{array}{cr}\text { R/ Ekstrak } & 2,5 \mathrm{~g} \\ \text { Adeps lanae } & 14,62 \mathrm{~g} \\ \text { Vaselin album } & 82,88 \mathrm{~g} \\ \text { m.f.salep } & 100 \mathrm{~g}\end{array}$

Formula II

R/ Ekstrak $5 \mathrm{~g}$

Adeps lanae $14,25 \mathrm{~g}$

Vaselin album m.f.salep

$80,75 \mathrm{~g}$

Formula III

R/ Ekstrak $7,5 \mathrm{~g}$

Adeps lanae $13,88 \mathrm{~g}$

Vaselin album

m.f.salep

$78,62 \mathrm{~g}$

$100 \mathrm{~g}$

2.2.3 Penyiapan hewan uji dan pembuatan luka sayat
Hewan uji yang digunakan pada penelitian ini adalah kelinci jantan galur (New Zealand White) sebanyak 4 ekor yang berumur 2-3 bulan dengan berat badan antara 1,2-1,5 kg. Sebelum pembuatan luka, kelinci diaklimatisasi selama 5 hari dengan tujuan untuk membiasakan hidup pada lingkungan dan perlakuan yang baru. Sehari sebelum pembuatan luka, punggung kelinci dibersihkan dari bulu sampai licin dengan dibuat 6 area perlakuan dengan jarak antar area $2 \mathrm{~cm}$. Area yang sudah dicukur dibersihkan dengan alkohol $70 \%$ kemudian diistirahatkan selama 24 jam. Pada keesokan harinya, pada masingmasing bagian yang sudah ditandai kemudian disayat menggunakan pisau bisturi dengan panjang $2 \mathrm{~cm}$ dengan kedalaman $\pm 0,2 \mathrm{~cm}$ dengan cara memberi tanda pada bisturi yang telah diukur.

Pengolesan salep (F1: salep ekstrak 2,5\%, F2: salep ekstrak 5\%, F3: salep ekstrak 7,5\%, F4: Kontrol Negatif dan F5: Kontrol positif) pada setiap luka sayat dilakukan tiga kali sehari (tiap 8 jam). Kontrol negatif yang digunakan adalah basis salep tanpa ekstrak, sedangkan kontrol positif yang digunakan adalah salep povidone iodin $10 \%$. Pengamatan penyembuhan luka sayat pada kelinci dilakukan dengan cara melihat secara kasat mata dan mengukur panjangnya penyembuhan luka menggunakan jangka sorong yaitu dengan melihat adanya eritem, pembengkakan dan luka menutup. Pengukuran panjang luka awal yaitu $2 \mathrm{~cm}$ dengan kedalaman $0,1 \mathrm{~cm}$. Pengamatan dilakukan hingga luka dinyatakan sembuh. Kecepatan konsentrasi luka dilakukan dengan menggunakan rumus sebagai berikut (Rahman dkk., 2017):

$$
\% \text { Penyembuhan Luka }=\frac{\text { Area Penyembuhan }}{\text { Area Luka Awal }} \times 100
$$


DOI : https://doi.org/10.24843/JFU.2020.v09.i02.p06

pISSN: 2301-7716; eISSN: 2622-4607

Jurnal Farmasi Udayana, Spesial Issue Desember 2020, 180-186

Area Penyembuhan $=$ Area luka awal - Area luka akhir

\section{HASIL}

\section{Uji Homogenitas}

Salep diambil dari bagian atas, tengah dan bawah kemudian salep dioleskan pada sekeping kaca objek. Hasil pengamatan dapat dilihat pada tabel di bawah ini:

Tabel 1. Hasil Uji Homogenitas Salep

\begin{tabular}{ccc}
\hline No & $\begin{array}{c}\text { Jenis } \\
\text { Salep }\end{array}$ & Homogenitas \\
\hline 1 & F1 & Homogen, tidak menggumpal \\
2 & F2 & Homogen, tidak menggumpal \\
3 & F3 & Homogen, tidak menggumpal \\
4 & F4 & Homogen, tidak menggumpal \\
5 & F5 & Homogen, tidak menggumpal \\
\hline
\end{tabular}

\section{Uji pH}

Uji pH pada salep merupakan pengujian untuk mengetahui kadar keasambasaan dari sediaan salep. Pengukuran $\mathrm{pH}$ dilakukan dengan menggunakan $\mathrm{pH}$ universal. Hasil pengamatan dapat dilihat dibawah ini:

Tabel 2. Hasil Uji pH Salep

\begin{tabular}{ccc}
\hline No & Jenis Salep & $\mathbf{p H}$ \\
\hline 1 & F1 & 6 \\
2 & F2 & 6 \\
3 & F3 & 6 \\
4 & F4 & 6 \\
5 & F5 & 7 \\
\hline
\end{tabular}

Sediaan salep yang dibuat harus sesuai dengan pH normal ideal kulit yaitu 4,5 - 6,5 .Pengujian $\mathrm{pH}$ salep dilakukan dengan menggunakan $\mathrm{pH}$ universal yang dicelupkan pada masing-masing salep, kemudian dilihat dan dicocokkan perubahan warna dengan standar warna $\mathrm{pH}$ universal. Hasil pengujian diperoleh $\mathrm{pH}$ ke tiga salep ekstrak bunga ginje adalah 6 maka salep ekstrak bunga ginje memiliki pH normal ideal kulit sehingga salep ekstrak bunga ginje tidak mengiritasi kulit.

\section{Uji Daya Sebar}

Salep ekstrak bunga ginje diuji daya sebarnya pada sekeping kaca untuk mengetahui kemampuan salep tersebut menyebar dengan penambahan beban 100 gram. Hasil pengujian dapat dilihat di bawah ini:

Tabel 3. Hasil Uji Daya Sebar salep

\begin{tabular}{ccc}
\hline No & Jenis Salep & Daya Sebar $(\mathrm{cm})$ \\
\hline 1 & F1 & 3,9 \\
2 & F2 & 3,8 \\
3 & F3 & 3,2 \\
4 & F4 & 4 \\
5 & F5 & 4,2 \\
\hline
\end{tabular}

Pengujian terhadap daya sebar salep menunjukan bahwa salep dapat tersebar merata pada permukaan kaca. Semakin luas daya sebar maka akan semakin cepat penyebaran dengan hanya pemberian sedikit kontak obat dengan permukaan akan meningkat. Daya sebar yang baik yaitu 5,6-6,4 cm (Alka Garg, Deepika Aggarwal, Sanjay Garg, 2002). Hasil pengamatan menunjukan bahwa salep ekstrak bunga ginje konsentrasi $2,5 \%, 5 \%, 7,5 \%$, basis salep maupun salep povidon iodin tidak mempunyai daya sebar yang sesuai karena daya sebarnya tidak masuk kedalam renge daya sebar salep yang baik.

\section{Efektivitas Penyembuhan Luka Sayat}

Luka sayat dihari pertama terjadi reaksi vaskuler dimana permukaan luka dialiri darah selama beberapa menit, dan kemudian pendarahan berhenti dengan sendirinya dikarenakan pembuluh darah yang terputus mengalami konstriksi dan retraksi. Luka akan memar pada hari selanjutnya yang 
DOI : https://doi.org/10.24843/JFU.2020.v09.i02.p06

pISSN: 2301-7716; eISSN: 2622-4607

Jurnal Farmasi Udayana, Spesial Issue Desember 2020, 180-186

menandakan terjadi fase inflamasi. Hal ini berguna sebagai proteksi terhadap jaringan yang mengalami kerusakan untuk tidak mengalami infeksi serta meluasnya luka secara tidak terkendali.

Tabel 4. Persentase Penyembuhan Luka Sayat pada Kelinci Jantan (New Zaland White)

\begin{tabular}{|c|c|c|c|c|c|c|c|c|c|c|c|c|}
\hline & $\begin{array}{l}\text { H1 } \\
(\%)\end{array}$ & $\begin{array}{l}\text { H2 } \\
(\%)\end{array}$ & $\begin{array}{c}\text { H3 } \\
(\%)\end{array}$ & $\begin{array}{c}\mathrm{H4} \\
(\%)\end{array}$ & $\begin{array}{l}\text { H5 } \\
(\%)\end{array}$ & $\begin{array}{l}\text { H6 } \\
(\%)\end{array}$ & $\begin{array}{l}\text { H7 } \\
(\%)\end{array}$ & $\begin{array}{c}\text { H8 } \\
(\%)\end{array}$ & $\begin{array}{l}\text { H9 } \\
(\%)\end{array}$ & $\begin{array}{l}\text { H10 } \\
(\%)\end{array}$ & $\begin{array}{l}\text { H11 } \\
(\%)\end{array}$ & $\begin{array}{l}\text { H12 } \\
(\%)\end{array}$ \\
\hline F1 & 0 & 5 & 11,25 & 18,75 & 22,5 & 30 & 35 & 48,75 & 93,75 & 100 & 100 & 100 \\
\hline F2 & 0 & 6,25 & 8,75 & 15 & 18,75 & 25 & 32,5 & 43,75 & 95 & 100 & 100 & 100 \\
\hline F3 & 0 & 6,25 & 10 & 18,75 & 25 & 32,5 & 47,5 & 65 & 100 & 100 & 100 & 100 \\
\hline F4 & 0 & 3,75 & 6,25 & 20 & 25 & 31,25 & 35 & 43,75 & 81,25 & 91,25 & 100 & 100 \\
\hline F5 & 0 & 0 & 5 & 7,5 & 18,75 & 18,75 & 22,5 & 33,75 & 53,75 & 58,75 & 66,25 & 85 \\
\hline
\end{tabular}

Berdasarkan tabel di atas dapat dilihat perbedaan waktu penyembuhan luka sayat pada kelinci jantan (New Zealand White). Dari ke 3 salep ekstrak bunga ginje, salep dengan konsentrasi $7,5 \%$ lebih cepat dalam penyembuhan luka dibandingkan dengan salep ekstrak bunga ginje konsentrasi 2,5\% dan 5\%. Sedangkan penyembuhan dengan menggunakan salep povidon iodin sembuh 2 hari lebih lama dari salep ekstrak bunga ginje 7,5\%. Hal ini disebabkan karena povidon iodin berperan sebagai antiseptik tidak untuk mempercepat waktu penyembuhan luka, melainkan mencegah luka terinfeksi mikroorganisme lainnya. Sedangkan pada salep ekstrak bunga ginje yang mengandung flavonoid dapat mempercepat waktu penyembuhan luka dengan menghambat pembentukan prostaglandin yang dapat menimbulkan fase inflamasi sehingga fase inflamasi pada luka yang diberikan perlakuan salep ekstrak bunga ginje sangat singkat (Shoskes. DA, 1999). Senyawa metabolit sekunder Thevetin (glikosida steroid) yang terdapat pada bunga ginje dapat berperan sebagai antibakteri yang dapat mencegah luka terinfeksi oleh mikroorganisme lain sehingga salep ekstrak bunga ginje dapat berfungsi sebagai penyembuh luka sayat dan antiseptik (Eka Yudha pratama, 2015).

Pada kelompok kelinci yang diberikan perlakuan salep ekstrak bunga ginje 2,5\% luka menutup sempurna pada hari ke-10. Pada hari pertama dan hari ke dua luka masih terlihat adanya darah membeku dan memar pada tepi luka, namun pada hari ketiga terlihat luka membengkak dan merah yang menunjukkan terjadinya fase inflamasi, pada hari ke 6 tepi luka mulai mengering dan sedikit bernanah, pada hari ke 7 keropeng mulai mengelupas dan kulit terlihat berwarna merah muda. Pada hari ke 10 warna kulit sedikit menyamai warna kulit yang tidak terluka namun kulit sedikit mengerut.

Pada kelompok kelinci yang diberikan perlakuan salep ekstrak bunga ginje 5\% luka menutup pada hari ke 10. Pada kelompok ini keropeng terbentuk pada hari ke 7, keropeng yang kering hampir menutupi seluruh luka. Pada hari ke 9 keropeng mulai terkelupas dan sedikit memar, pada hari ke 10 keropeng terkelupas sempurna dan kulit menjadi warna merah muda. 
DOI : https://doi.org/10.24843/JFU.2020.v09.i02.p06

pISSN: 2301-7716; eISSN: 2622-4607

Jurnal Farmasi Udayana, Spesial Issue Desember 2020, 180-186

Pada kelompok kelinci yang diberikan perlakuan salep ekstrak bunga ginje 7,5\%. Tahap penyembuhan luka pada konsentrasi $7,5 \%$ lebih cepat namun penyembuhan secara sempurna dapat dilihat pada hari ke 9. Pada luka ke 3 dengan pemberian salep ekstrak bunga ginje 7,5\% mulai mengering pada hari ke 3 dan membentuk keropeng pada hari ke 5, tepi luka membengkak dan merah pada hari ke 6 ini menunjukkan terjadinya fase inflamasi pada luka. Keropeng mengelupas pada hari ke 8 dan kulit terlihat lebih muda. Pada hari ke 9 warna kulit hampir manyamai warna kulit yang tidak terluka namun sedikit mengerut hal ini disebabkan kerana pembentukan jaringan granulasi pada luka.

\section{PEMBAHASAN}

Kelompok kelinci yang diberikan perlakuan salep povidon iodin sebagai kelompok kontrol positif. Luka sayat sangat cepat mengering namun keropeng yang disebabkan karena penumpukan iodin pada luka menyebabkan keropeng menebal dan lama terkelupas, sehingga luka dapat sembuh pada hari ke 11. Pada kelompok kelinci yang diberikan perlakuan basis salep berupa vaselin album dan adeps lanae sebagai kelmpok konrol negatif. Pada hari ke 12 masih terlihat adanya nanah disekitar luka. Hal ini disebabkan karena basis salep tidak memiliki aktivitas sebagai penyembuh luka sayat, melainkan sebagai emolient atau pelembab. Sehingga apabila diberikan pada luka, luka akan menjadi basah dan bernanah dan akan sulit untuk mengering.

Semua kelompok perlakuan menunjukan adanya peningkatan dalam penyembuhan luka sayat, namun penyembuhan luka sayat yang diberikan salep ekstrak bunga ginje 7,5\% dapat lebih cepat sembuh dibandingkan dengan salep dengan konsentrasi yang lain. Dan salep ekstrak bunga ginje $7,5 \%$ dapat menyembuhkan luka sayat lebih cepat dibandingkan dengan kontrol positif yaitu povidon iodin. Hasil penelitian ini dapat menunjukkan bahwa salep ekstrak bunga ginje memiliki efektivitas sebagai penyembuh luka sayat. Kandungan kuersentin yang termasuk kedalam golongan flavonoid memberikan efektivitas sebagai penyembuh luka sayat dengan cara menghambat pembentukan prostaglandin, leukotrin dan histamin sebagai pemicu terjadinya inflamasi (Shah, 2016).

Selain itu kandungan tanin yang terdapat dalam ekstrak bunga ginje dapat berfungsi sebagai adstringen yang dapat menyebabkan penciutan pori-pori kulit, memperkeras kulit, menghentikan eksudat dan pendarahan ringan, sehingga menutupi luka dan mencegah pendarahan yang biasa timbul pada luka. Senyawa Thevetin (glikosida steroid) yang terdapat pada bunga ginje dapat berperan sebagai antibakteri yang dapat mencegah luka terinfeksi oleh mikroorganisme lain sehingga salep ekstrak bunga ginje dapat berfungsi sebagai penyembuh luka sayat dan antiseptik (Eka Yudha pratama, 2015).

\section{Analisis SPSS}

Hasil uji dilanjutkan dengan pengolahan data melalui statistik dan visual. Uji normalitas dilakukan untuk mengetahui apakah data berdistribusi normal atau tidak. Normalitas data merupakan hal yang penting karena dengan data yang terdistribusi normal, maka data tersebut dianggap dapat mewakili populasi (Priyatno, 2014). Karena data yang dimasukkan < 50 maka hasil yang digunakan yaitu hasil pada Shapiro-Wilk, karena $\mathrm{p}<0,05$ maka data terdistribusi normal.

Analisa dilanjutkan dengan metode analisis varian dua arah digunakan untuk 
DOI : https://doi.org/10.24843/JFU.2020.v09.i02.p06

pISSN: 2301-7716; eISSN: 2622-4607

Jurnal Farmasi Udayana, Spesial Issue Desember 2020, 180-186

menguji hipotesis komparatif rata-rata sampel bila data yang didapat dalam penelitian berupa kategorisasi terhadap sampel kedalam beberapa kelompok, variabel dikatakan signifikan apabila $p<0,05$. Berdasarkan tabel diatas hasil yang didapat pada analisis Two Way Anova yaitu variabel formulasi salep mempengaruhi persentase penyembuhan luka sayat ada perbedaaan pada tiap kelompok secara signifikan $(\mathrm{p}=0,000)$, begitu juga dengan variabel waktu penyembuhan luka dengan persentase persentase penyembuhan luka, terdapat perbedaan yang signifikan diantara keduanya $(\mathrm{p}=0,000)$.

Selanjutnya data dianalisa dengan menggunakana Turkey HSD untuk mengetahui perbedaan rata-rata secara signifikan antar kelompok perlakuan. Hasil yang didapat yaitu terdapat perbedaan secara bermakna antara salep ekstrak bunga ginje dengan kontrol negatif dan tidak bermakna antara salep ekstrak bunga ginje konsentrasi 2,5\%, 5\% dan 7,5\% terhadap kontrol positif (Povidon Iodin 10\%).

\section{KESIMPULAN}

Salep ekstrak bunga ginje memiliki efektivitas sebagai penyembuh luka sayat terhadap kelinci jantan New Zealand White, salep ekstrak bunga ginje 7,5\% dapat menyembuhkan luka sayat lebih cepat dibandingkan dengan salep ekstrak bunga ginje 2,5\%,5\% dan salep ekstrak bunga ginje memiliki evaluasi sediaan fisik yang baik.

\section{DAFTAR PUSTAKA}

1. Agoes, Goeswin., (2006). 'Pengembangan Sediaan Farmasi'., ITB : Bandung

2. Alka Garg, Deepika Aggarwal, Sanjay Garg, and A. K. S. (2002) 'Spreading of Semisolid Formulations', (September).
3. Anief, M., 2010., Ilmu Meracik Obat., Cetakan Kesepuluh Yogyakarta: Penerbit Gadjah Mada University Press., Hal: 52.

4. Dan, P. dkk. (2008) 'Penggunaan Dan Penanganan Hewan Coba Rodensia Dalam Penelitian Sesuai Dengan Kesejahteraan Hewan, pp. 1-81.

5. Eka Yudha pratama (2015) 'Aktivitas Antimikroba Ekstrak Daun Dan Buah Ginje (Thevetia Peruviana) Terhadap Staphylococcus aureus dan Candida albicans Secara In Vitro'. Skripsi. Fakultas Keguruan dan Ilmu Pendidikan . UMS

6. Priyatno, Duwi. (2014). SPSS Pengolahan Data Terpraktis. Yogyakarta: CV: Andioffset

7. Rahman, N. et al. (2017) 'Wound healing potentials of Thevetia peruviana: Antioxidants and inflammatory markers criteria', Journal of Traditional and Complementary Medicine. Elsevier Ltd, 7(4), pp. 519-525. doi: 10.1016/j.jtcme.2017.01.005.

8. Senja, R. Y., Hidayati, N. R. and Setyaningsih, I. (2014). 'Uji Efektivitas Salep Ekstrak Daun Mengkudu (Morinda citrifolia L.) terhadap Luka Sayat Pada Kelinci Jantan (Oryctolagus cuniculus)', Medical Sains. pp. 100-107.

9. Shah, P. M. (2016) 'Quercetin - A Flavonoid: A Systematic Review', Saveetha Dental College and Hospitals, Chennai. 8(8), pp. 878-880.

10. Sutawijaya. R. B., 2009. Gawat Darurat Panduan Kesehatan Wajib di Rumah Sakit Anda., Yogyakarta: Aulia Publishing.

11. Thilagavathi, R. and Kavitha, H. P. (2010) 'Isolation , Characterization and AntiInflammatory Property of Thevetia Peruviana', Journal of Chemistry: 7(4), pp. 1584-1590.

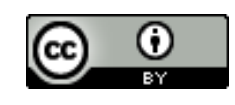

This work is licensed under a Creative Commons Attribution 4.0 International License 